\title{
Regional effects of the COVID-19 pandemic and policy responses in Hungary
}

\author{
S.Z. Kovács ${ }^{1} \bowtie$, B. Koós ${ }^{2}$, A. Uzzoli ${ }^{2}$, B. Páger ${ }^{1}$, I. Egyed ${ }^{1}$ \\ ${ }^{1}$ CERS Institute for Regional Studies, Pécs, Hungary; kovacs.sandor@krtk.mta.hu \\ ${ }^{2}$ CERS Institute for Regional Studies, Budapest, Hungary
}

\section{ABSTRACT}

Relevance. The new coronavirus pandemic (COVID-19) has brought major changes to everyday life and economy in 2020. The impacts of the pandemic are still difficult to measure and interpret. This paper analyses the key socio-economic factors that shaped the course of the pandemic and its regional effects in Hungary. Research objective. The aim of this paper is to provide a secondary data-based analysis of regional disparities in Hungary as well as the implications of the coronavirus pandemic and the related policy responses. Data and methodology. The analysis consisted of the three stages: first, we processed the official epidemiologic data related to the coronavirus pandemic and the territorial patterns of infections as well as the data on the socio-economic impacts of the lockdown (on retail trade, employment, tourism, local governments' revenues, etc.). Second, we collected the data related to the socio-economic effects of the pandemic and revealed the territorial impacts of the crisis. Finally, we evaluated the government's measures and interventions introduced in the first wave of the pandemic in terms of their efficiency. Results Our results demonstrate that while the epicentre of the pandemic was the capital city and its surrounding area, the socio-economic impacts of containment measures implemented by the Hungarian government were felt across the whole country. In some areas, the lockdown measures could have been unreasonably tight as no reasonable justification for these restrictions was provided. Therefore, territorial monitoring and development of regionally differentiated policies are the main tasks in preparation for further waves of the pandemic. In our opinion, it is necessary to devise an action plan that would regulate the protocols of prevention and protection in connection with the regional focal points (hospitals, nursing homes, schools, etc.) and their immediate surroundings. Conclusions. Although territorial aspects have been taken into account by the government in their efforts to contain the pandemic in Hungary, they have been given significantly less attention in terms of socio-economic support. Thus, as the article makes clear, it is important to devise and implement regionally differentiated policies of containment as well as socio-economic protection measures.

\section{KEYWORDS}

COVID-19, pandemic, socioeconomic impacts, territorial inequality, Hungary

\section{FOR CITATION}

Kovács, S.Z., Koós, B., Uzzoli, A., Páger, B., \& Egyed, I. (2020)

Regional effects of the COVID-19 pandemic and policy responses in Hungary. R-economy, 6(3), 208-221. doi: $10.15826 /$ recon.2020.6.3.018

\section{Региональные последствия пандемии COVID-19 и меры правительства в Венгрии}

\author{
Ш.Ж. Ковач ${ }^{1} \bowtie$, Б. Кош ${ }^{2}$, А. Уццоли ${ }^{2}$, Б. Пагер ${ }^{1}$, И. Едьед ${ }^{1}$ \\ ${ }^{1}$ Институт региональных исследований CERS, Печ, Венгрия; kovacs.sandor@krtk.mta.hu \\ ${ }^{2}$ Институт региональных исследований CERS, Будапешт, Венгрия
}

\begin{abstract}
АННОТАЦИЯ
Актуальность. Новая пандемия коронавируса (COVID-19) внесла серьезные изменения в повседневную жизнь и экономику в 2020 году. Воздействие пандемии по-прежнему трудно измерить и интерпретировать. В данной статье анализируются ключевые социально-экономические факторы, которые сформировали течение пандемии и ее региональные последствия в Венгрии. Цель исследования. Цель этого документа - предоставить вторичный анализ региональных различий в Венгрии на основе данных, а также последствий пандемии коронавируса и соответствующих ответных мер правительства. Данные и методы. Анализ состоял из трех этапов: во-первых, мы обработали официальные эпидемиологи-
\end{abstract}

\section{КЛЮЧЕВЫЕ СЛОВА}

COVID-19, пандемия, социально-экономические последствия, территориальное неравенство, Венгрия 
ческие данные, связанные с пандемией коронавируса и территориальными структурами инфекций, а также данные о социально-экономических последствиях ограничений (на розничную торговлю, занятость, туризм, доходы органов местного самоуправления и т.д.). Во-вторых, мы собрали данные о социально-экономических последствиях пандемии и выявили территориальные последствия кризиса. Наконец, мы оценили меры вмешательства правительства, введенные в ходе первой волны пандемии, с точки зрения их эффективности. Результаты. Наши результаты показывают, что, хотя эпицентром пандемии была столица и ее окрестности, социально-экономические последствия ограничительных мер, введенных правительством Венгрии, ощущались по всей стране. В некоторых районах меры изоляции могли быть неоправданно жесткими, поскольку не было предоставлено разумного обоснования для этих ограничений. Следовательно, территориальный мониторинг и разработка регионально дифференцированной политики являются основными задачами при подготовке к новым волнам пандемии. По нашему мнению, необходимо разработать план действий, который регулировал бы профилактику и защиту в координации с региональными центрами (больницами, домами престарелых, школами и т.д.) и их непосредственным окружением. Выводы. Хотя территориальные аспекты были приняты во внимание правительством в усилиях по сдерживанию пандемии в Венгрии, им уделялось значительно меньше внимания с точки зрения социально-экономической поддержки. Таким образом, как поясняется в статье, важно разработать и реализовать дифференцированную по регионам ограничительную политику, а также меры социально-экономической защиты.

\section{ДЛЯ ЦИТИРОВАНИЯ}

Kovács, S.Z., Koós, B., Uzzoli, A., Páger, B., \& Egyed, I. (2020)

Regional effects of the COVID-19 pandemic and policy responses in Hungary. R-economy, 6(3), 208-221.

doi: $10.15826 /$ recon.2020.6.3.018

\section{Introduction}

Assessment of the short-, medium- and longterm effects of the new COVID-19 pandemic in 2020 and its territorial implications is a challenging task. The social and economic impacts of the pandemic are so profound and complex that it is difficult to predict what dramatic consequences they will lead to in the future. The efforts to curb the spread of the coronavirus gave rise to a number of solutions aimed at reducing the frequency of personal interactions such as remote working schemes and remote learning. Although such solutions are not new, the pace of their adoption and interiorization is remarkable (Lennert, 2020). At the same time there is a pressing demand for efficient policy interventions and the elaboration of novel solutions (Gombos et al., 2020). More in-depth interdisciplinary research is required to gain a better understanding of how the pandemic and the ensuing economic crisis are reshaping the spatial patterns of territorial inequalities, affecting territorial processes and contributing to the emergence of unprecedented territorial inequalities. It is also important to assess the demand for territorially sensitive interventions and policies aimed at containing the pandemic and mitigating its socio-economic impacts.

The primary aim of the study is to provide an overview of the 2020 COVID-19 pandemic, its various socio-economic impacts and territorial implications by focusing on the case of Hungary. The two main objectives constituted the framework for our analysis:

Objective 1: Assessment of socio-economic effects that occurred during the first wave of the new coronavirus pandemic (early March - end of July 2020). We sought to describe the main characteristics of the crisis triggered by the pandemic (e.g. the impact of COVID-19 on individuals and businesses).

Objective 2: Assessment of policy responses to mitigate these socio-economic effects. The analysis covers national measures and policies for social and economic protection aimed at containing the pandemic and countering its regional effects.

The scope of the paper - based on Objective 1 - is too broad, yet it may provide comprehensive information on the socio-economic effects of the pandemic in Hungary. Nonetheless, the paper does not intend to review the full spectrum of socio-economic implications, narrowing the focus to economic effects instead. The multidimensional evaluation of effects - based on $\mathrm{Ob}$ jective 2 - was conducted with a crucial emphasis on policy responses. The emphasis was on evaluating the territorial adequacy of economy protection measures and other policy interventions and their capacity to tackle territorially differentiated socio-economic implications. 


\section{Data and Methods}

The paper is mostly descriptive, because its methodology is built on secondary data-based analysis, literature review and content analysis. The data were taken from official sources such as the Hungarian Central Statistical Office, koronavirus.gov.hu. The logical structure of the analyses was as follows: first, we processed the epidemiologic data related to the coronavirus pandemic and the territorial patterns of infections. Second, we collected the data related to the socio-economic effects of the pandemic and revealed the territorial impacts of the crisis.

Finally, we evaluated the government's sectoral measures and interventions introduced in the first wave of the pandemic in terms of their efficiency.

The limitations of the study stem from the lack of detailed socio-economic territorial data, which is why we decided to provide a general overview of the situation.

The research results may be used by policy-makers to prepare for the second wave of the pandemic and to devise measures for mitigating adverse impacts.

\section{The Main Features of the First Wave of the New Coronavirus Pandemic in Hungary}

The COVID-19 pandemic started in the Chinese city of Wuhan in December 2019. After the first case was detected, the virus spread worldwide within a few months, leading to the declaration of a pandemic by the World Health Organization (WHO) on $11^{\text {st }}$ March 2020. The first two new coronavirus cases were detected in Hungary on $4^{\text {th }}$ March 2020, and on $11^{\text {st }}$ March, after which the government declared an epidemic emergency in the country until $18^{\text {th }}$ June. By $31^{\text {st }}$ July 2020, a total number of 4,505 confirmed cases had been registered in the country with the number of 596 total deaths, 556 active cases, and 3,353 recovered (Figure 1). Overall, $34 \%$ of active infected cases, $60 \%$ of the deceased and $45 \%$ of recovered patients were residents of the capital city (Budapest) in the first phase of pandemic. The mortality rate from the new coronavirus had reached $13.2 \%$ of the total infection rate by the end of July. People over 65 accounted for $80 \%$ of the deaths.

Examining the daily evolution of COVID-19 cases, five distinct phases can be identified during the first wave based on the pace of the spread of the epidemic in Hungary (Uzzoli, 2020) (Figure 2):

1. Phase of isolated cases $(04 / 03 / 2020$ 20/03/2020): in this period, the total number of cases remained below 100, the daily number of new cases in the first two weeks remained below 10 and later it oscillated between 10 to 15 . As of $21^{\text {st }}$ March 2020, the total number of infected people in the country had reached 103, and the daily number of new cases had shown a steady increase.

2 . Phase of group incidences $(21 / 03 / 2020-$ 09/04/2020): during this period, the average daily increase in the number of cases was 45 . The lowest daily number of new cases was recorded on $6^{\text {th }}$ April 2020 (11 persons), while the highest was registered on $9^{\text {th }}$ April 2020 (85 people). By the end of this period, the total number of cases had exceeded 900 .

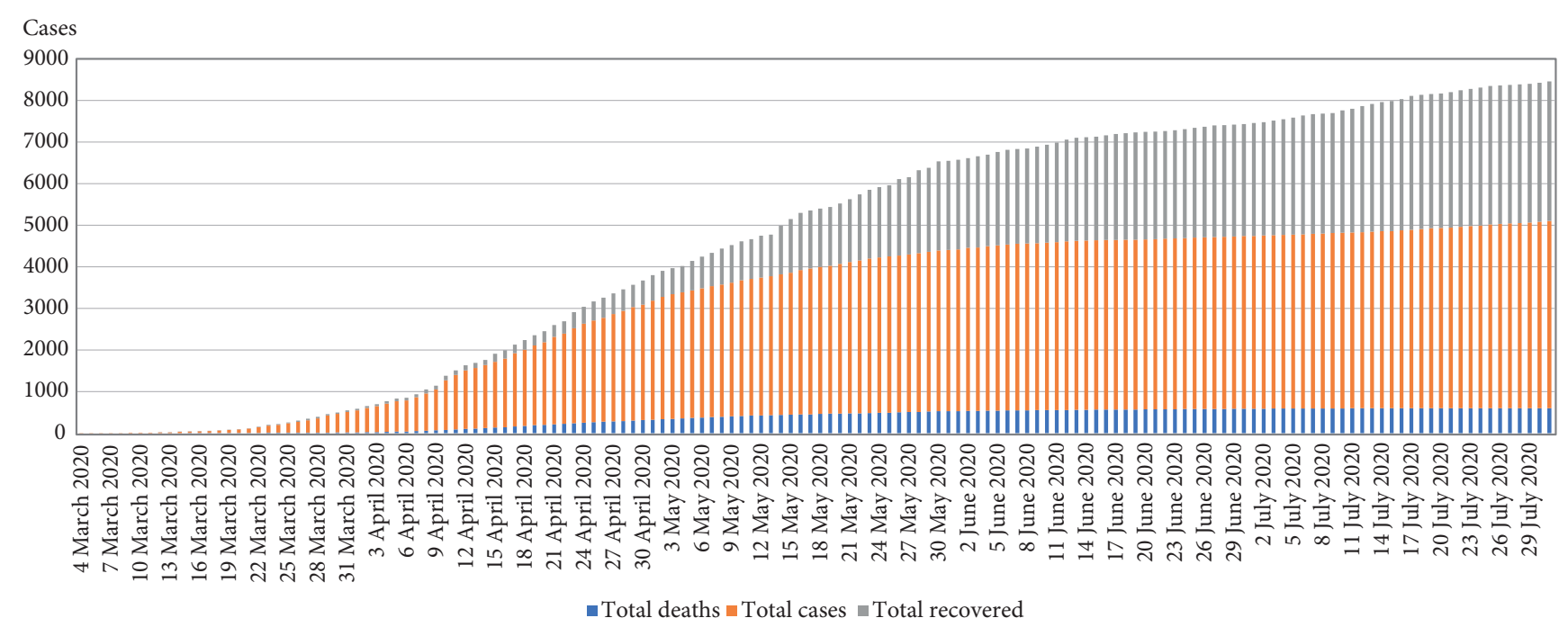

Figure 1. Morbidity and mortality data of COVID-19 in Hungary (04/03/2020 - 31/07/2020) Source: Official Information Website of Coronavirus Pandemic in Hungary http://abouthungary.hu/ 
3. Phase of a rising number of group incidences $(10 / 04 / 2020-23 / 04 / 2020)$ : during this period, the spread of the epidemic accelerated. The total number of cases exceeded 2,000, and the daily number of new cases frequently exceeded 100 . The daily number of new cases was increasingly affected by the spread of the infection in institutional hotbeds (nursing homes).

4. Phase of a declining number of group incidences (24/04/2020 - 13/06/2020): during this period, the daily number of confirmed cases dropped below 100 and showed a steady decline.
5. Phase of a stagnant number of isolated cases (from 14/06/2020): in this period, the daily number of new cases generally remained below 10 , similarly to the initial phase of the epidemic. A slight increase was detected in the daily number of new cases between $16^{\text {th }}$ and $19^{\text {th }}$ July, which, however, was linked to a regional or institutional hotspot and was easy to isolate.

The county-level distribution of new cases in Hungary shows that the levels above average were characteristic of the capital city (Budapest) and Pest and Fejér counties and points to an eastwest divide within the country (Figure 3). If we

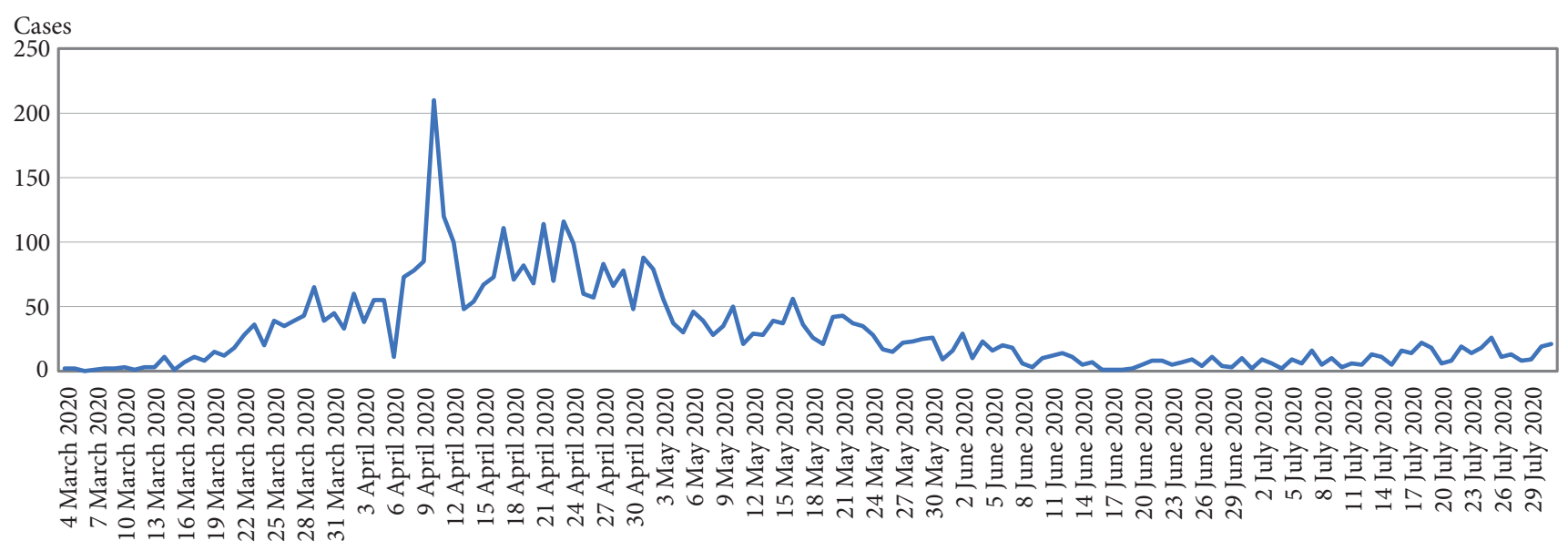

Figure 2. Daily number of new cases in Hungary (04/03/2020 - 31/07/2020) Source: Official Information Website of Coronavirus Pandemic in Hungary http://abouthungary.hu/

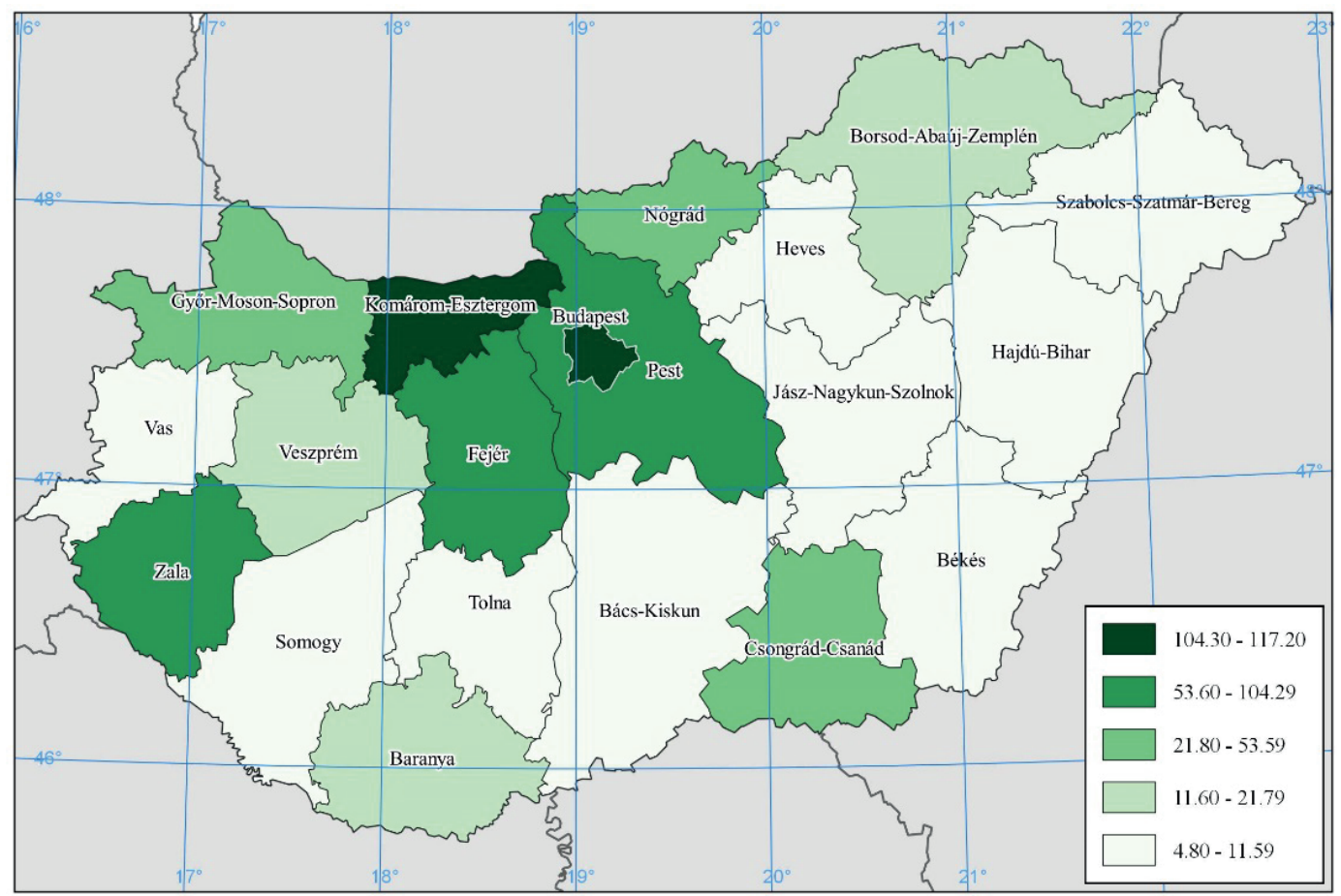

Figure 3. All confirmed cases in the counties of Hungary (case per 100,000 inhabitants) $(04 / 03 / 2020$ - 31/07/2020)

Source: Official Information Website of Coronavirus Pandemic in Hungary http://abouthungary.hu/ 
look at the total number of infected persons per 100,000 inhabitants during the first wave of the epidemic, we shall see that the eastern half of Hungary (except for Csongrád-Csanád county) was less affected and had a lower number of new cases. From the end of April 2020, besides Budapest and Pest county, an increasing number of new infected cases was detected predominantly in the western counties (Fejér, Komárom-Esztergom, Veszprém, Zala), and from the beginning of July, the daily number of new infections was on the rise in the eastern part of the country, in Borsod-Abaúj-Zemplén and Csongrád-Csanád and Hajdú-Bihar counties, respectively. If we look at the spatial diffusion of the pandemic in the first half of 2020, we can see territorial (Budapest, Pest county) and institutional (hospitals, nursing homes) hotspots (Kemenesi et al., 2020).

The short-term health consequences of the new coronavirus pandemic included the growing demand for the hospitalisation of infected patients: as the number of such patients grew, so did the risks of overburdening the health care system and the risks of the country facing capacity shortages. In the medium to long term, a rise in the number of cases of non-communicable diseases can also be expected, since for a while non-coronavirus infected patients were denied access to health care services on various grounds (e.g. suspension of screening and the treatment of chronic patients), which may lead to deterioration of their health or to a rise in avoidable deaths (Kovács and Uzzoli, 2020). Social distancing during the epidemic may cause, among other things, a deterioration in people's mental health (Grünhut and Bodor, 2020). The new coronavirus pandemic is likely to shape territorial disparities of health inequalities in Hungary in the future, leading to their intensification and the emergence of new types of inequalities.

\section{Major Social and Economic Effects of the Pandemic in Hungary}

The pandemic fundamentally transformed everyday life and engendered novel social phenomena that are likely to persist in the long run. The restrictions led people to self-quarantine, switch to remote working or learning schemes. This, in turn, resulted in revalorisation of digital achievements and contributed to the importance of broadband internet access in various spheres (e.g. shopping, managing finances, entertainment) (Kerényi and Müller, 2019). However, a crucial problem in the domestic context is that despite the availability of digital platforms, they cannot be accessed everywhere and by everyone (Figure 4). In several cases, people are facing such problems as the lack of internet access or neces-

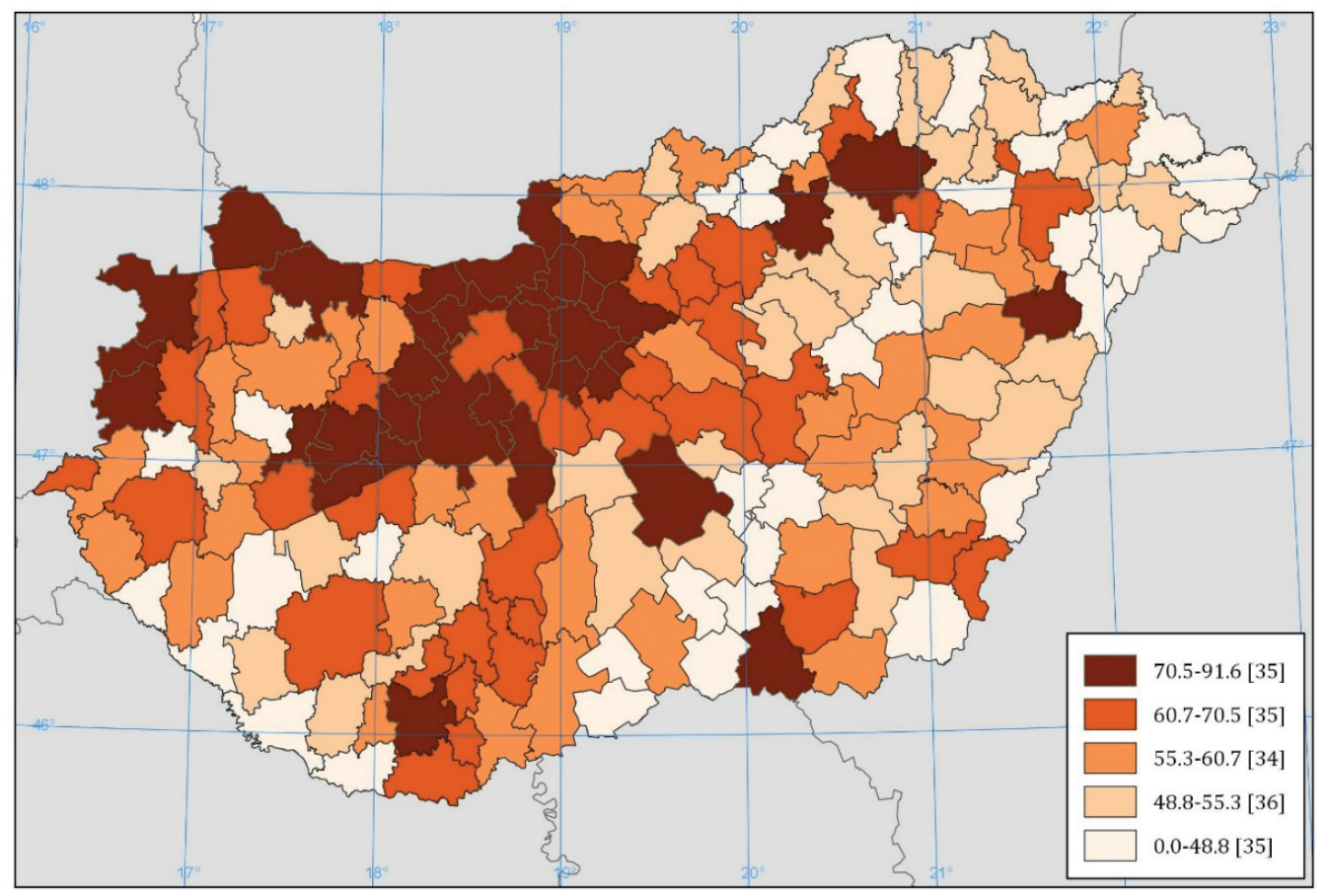

Figure 4. Wired internet subscriptions in Hungarian homesteads, \% (2018) Source: Koós, 2020, p. 176 
sary equipment or competence to use it (Kovács, 2020a). According to Hermann, who used the 2017 national data, roughly one-fifth of elementary school students are unable to participate in digital education because their family has no internet access or computer (Hermann, 2020).

Areas (rural, peripheral villages, homesteads) and social groups (low pension, impoverished, unemployed groups) most vulnerable to digital exclusion are also those subject to other socio-economic factors contributing to their slow growth (Koós, 2020). In addition to the digitalisation of supply, consumer attitudes on the demand side also need to be taken into account. Daily life has largely been moved to online platforms, with about a third of the population transitioning to e-administration (post office, telephone customer service, applications, customer portal, internet banking) and cashless payment practices where possible. Most of these trends imply persistent changes. In the financial sector, this change is twofold: the use of previously available digital products has increased significantly, and, to a lesser extent, new financial products have also appeared in non-personal electronic versions (kpmg.hu).

As in other parts of the world, digital services facilitating the minimization of personal encounters have gained increasing momentum in Hungary, highlighting the crucial role of the pandemic in the reduction of the country's digital gap. Within a few months, a two-decade gap was eliminated in various areas thanks to the use of digital services on a routine basis (for instance, for purchasing a bus ticket or making an appointment) by growing segments of the population. At the same time, there are significant territorial differences as in more economically advantaged, predominantly urban areas (the agglomeration of the capital city, county seats and their catchment areas), the majority of the population encountered no major difficulties in the digital transition with ICT tools and internet access widely available as well as the competence to use them. In contrast, in less developed, rural areas, particularly those belonging to external and internal peripheries, broad layers of society struggling to cope with the absence of general public and private services were unable to access digital services prioritized by the epidemic.

It should be noted that the coronavirus pandemic had far-reaching consequences for the private lives of individuals and the national econo- my as a whole. While the health and health care effects of the epidemic remained moderate (regarding the number of infected cases) in the first half of 2020, the economic impacts were much more severe. Drastic measures to contain the epidemic were implemented globally (curfew, restriction of border traffic). Initially affecting priority sectors (e.g. trade, hospitality, tourism), the economic slump affected - to a greater or lesser extent -all sectors and areas of the economy. The economy, after experiencing an upward trend in the first quarter, plunged into a significant downturn of 13.5 percent in the second quarter. The first signs of economic downturn were observed in the supply chain, due to the loss of Chinese suppliers, which put Hungarian manufacturing firms in a difficult situation. The negative effects were particularly visible in the manufacturing of vehicles and components and the manufacturing of electronic equipment, while the share of the import of medical devices increased. Subsequently, the closure of borders with neighbouring countries had negative repercussions on the labour market and tourism as well (Hajdú and Rácz, 2020).

Epidemiological measures implemented in mid-March resulted in a sharp decline in the performance of the services sector. In April 2020, the value of retail sales showed an average decrease of $10 \%$ compared to the previous year, with variable impacts across the country (Figure 5): in various western and several eastern districts a modest expansion was observed (KSH, 2020a).

By April 2020, international tourism had practically ceased to exist (passenger traffic at Budapest Airport dropping to 2\%) accompanied by a significant reduction in domestic traffic. The decline in tourism traffic affected each segment of tourism and hospitality, hitting particularly hard tourist destinations (Figure 6). The decline also affected local governments through the reduction in local tax revenues (KSH, 2020b; Kovács, 2020b). The adverse effects were felt by employees in the sectors of tourism and hospitality: one-fifth (18\%) of individual entrepreneurs, predominantly located in priority tourist destinations (Budapest, Lake Balaton) decided to suspend their operations.

In the case of agricultural firms, producers with a higher mobility, a well-established customer base and online presence displayed the greatest resilience to the crisis (Benedek et al., 2020).

In the rapidly changing labour market, between the fourth quarter of 2019 and the first 
quarter of 2020, the number of vacancies significantly decreased (KSH, 2020c).

The pandemic has had a negative impact on the financial markets of Hungary and Visegrad countries. It has affected the market participants' perception of the future price movement in financial markets (Czech et al., 2020).

Deteriorating economic performance had considerable implications for the labour de- mand, resulting in rising unemployment rates after several years of a steady decline. Looking at the general trend of increasing unemployment, we focused on two different aspects. Firstly, we examined the increase in the unemployment rate according to the legal status of settlements and our results show that this rate increased significantly in all categories, from small villages to the capital city. Secondly, we classified the set-

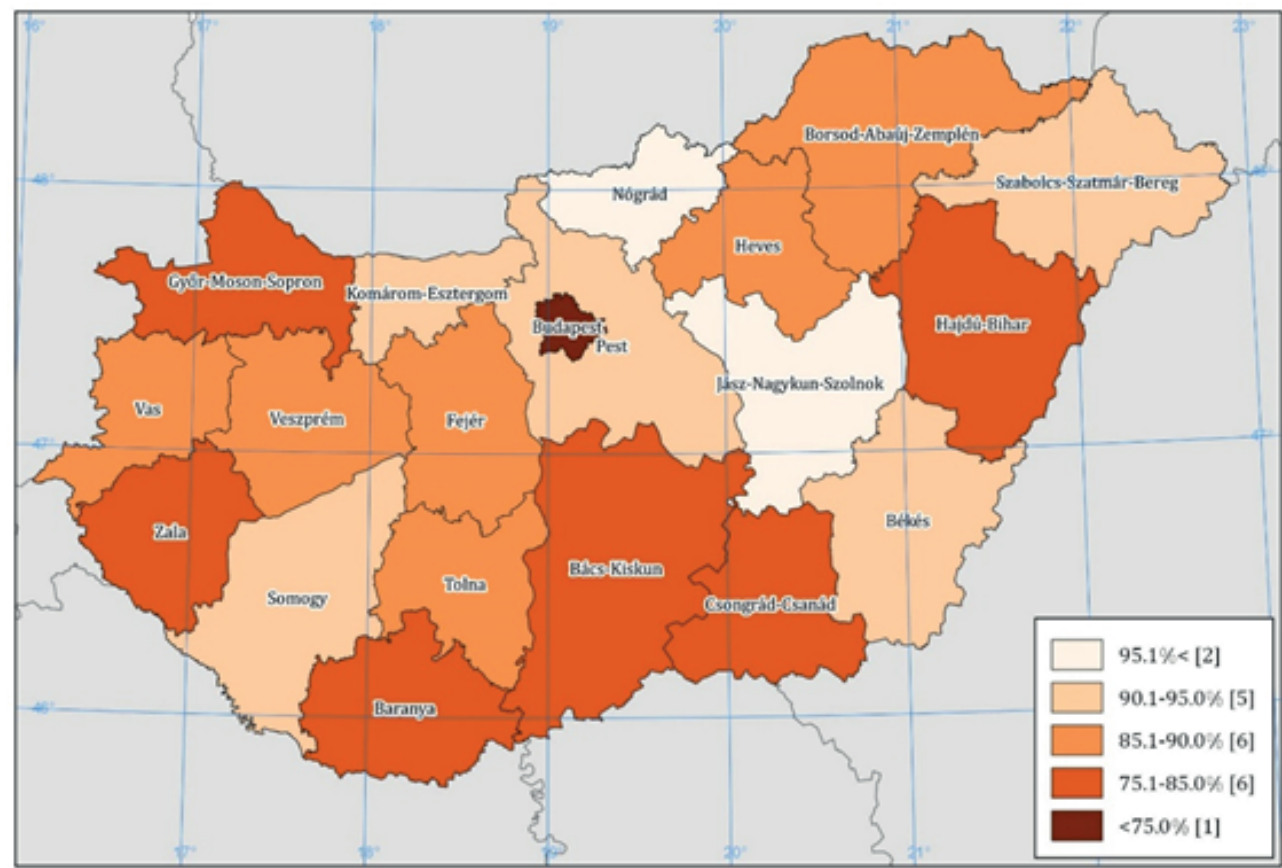

Figure 5. Volume index of retail trade by county in Hungary (April 2020) Source: Hungarian Central Statistical Office, 2020

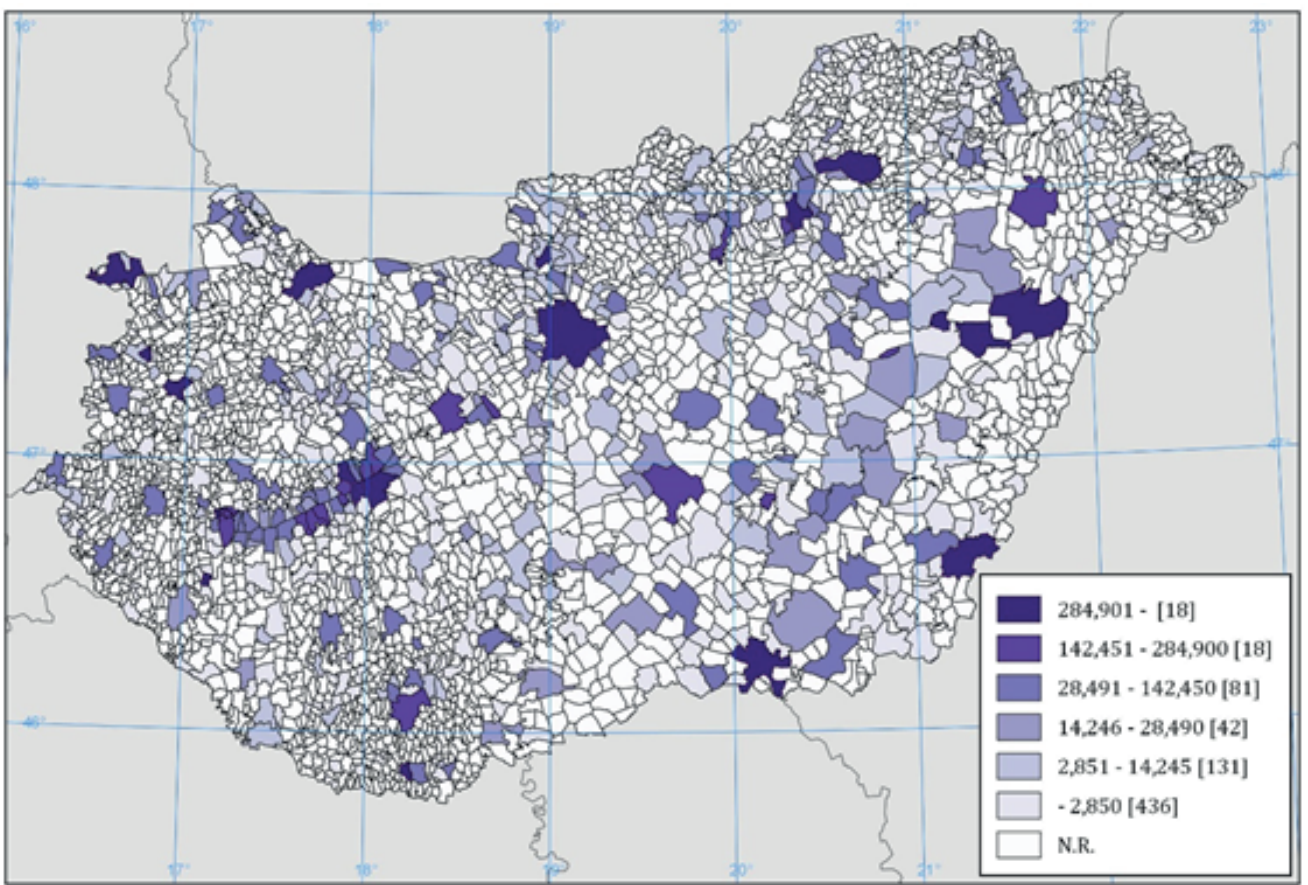

Figure 6. Tourism tax revenues of the local governments in Hungary, EUR (2017) Source: Kovács, 2020b. p. 193 
tlements, dividing them into four groups according to the Government Decree 105/2015 ${ }^{1}$. This document classifies all settlements depending on their social-economic status (demography, housing and living conditions, local economy, unemployment, infrastructure, and environment) and distinguishes the following types:

- beneficiary settlements from the socio-economic and infrastructural point of view, that is, the settlements that are disadvantaged in terms of all socio-economic factors;

- settlements with significant unemployment;

- non-beneficiary settlements, that is, the settlements with good local conditions (Table 1).

The increase in the unemployment rate was not uniform, with highest rates recorded in backward, typically peripheral settlements (attaining $13.7 \%$ through an increase of 2.5 percentage points), while prosperous settlements experienced a more moderate rise (a mere 0.84 percentage point rise was registered in Budapest between February and May 2020). The results are somewhat more nuanced if we consider the fact that people losing their livelihood do not register as unemployed in every case since the unemployment benefit, which may not exceed $€ 460$ gross per month, can be accessed for up to 90 days and only by those claimants who had been employed for at least 12 months over the previous 3 years. Potential beneficiaries in a more favourable position tended to prefer economic inactivity in the short term, hoping that their situation would soon be resolved.

\footnotetext{
${ }^{1}$ Government Decree 105/2015. about the classification and the conditions for classification of the beneficiary settlements. https://net.jogtar.hu/jogszabaly?docid=a1500105.kor (Download: 20. May 2020) (In Hungarian)
}

The pandemic generated some - rather temporary - favourable effects as well: quarantine orders led to diminished work-related vehicle use, ameliorating, in the short run, air quality in the capital and larger cities (Farkas and Kovács, 2020; Varjú et al., 2020). Many people switched to bicycle use, encouraged by the expansion of bike lanes in the capital. The role of parks and public spaces was somewhat upgraded under the curfew as urban residents used these spaces for their recreational leisure activities (Jóna, 2020).

To sum up, the COVID-19 pandemic had a major impact on the system of health care, engendering a plethora of novel social phenomena, and triggering, in the meantime, a significant decline or transformation of many economic sectors.

\section{Policy Responses to the New Coronavirus Pandemic and its Effects: Regional Dimension}

Governments are required to design new, innovative instruments to counter the socio-economic impacts of the new coronavirus induced crisis. Due to the diverse territorial impacts of the epidemic, there is some degree of uncertainty on whether territorially sensitive measures should feature among policy responses, and to what extent territorial aspects should be incorporated into these interventions.

The declaration of epidemiological emergency and the introduction of restrictive measures affected the entire territory of Hungary between $11^{\text {st }}$ March and $18^{\text {th }}$ June 2020. On $10^{\text {th }}$ April 2020, at the beginning of the Easter holiday period, municipalities were authorized to close various parts of their respective settlements (during the holiday, on weekends). Various territorially sen-

Table 1

Registered unemployed persons as percentage of the working-age population, according to the legal and beneficiary status of settlements in Hungary, \% (February 2020 - May 2020)

\begin{tabular}{|l|c|c|c|c|}
\hline & February 2020 & March 2020 & April 2020 & May 2020 \\
\hline Capital city & 1.41 & 1.39 & 1.75 & 2.25 \\
\hline Cities with county rights & 3.32 & 3.58 & 4.55 & 5.23 \\
\hline Cities & 4.21 & 4.69 & 5.64 & 6.12 \\
\hline Villages & 5.53 & 6.28 & 6.96 & 7.37 \\
\hline $\begin{array}{l}\text { Beneficiary settlements from the socio-economic and infrastructural } \\
\text { point of view }\end{array}$ & 7.80 & 8.73 & 9.46 & 9.72 \\
\hline Settlements with significant unemployment & 7.71 & 8.90 & 9.62 & 10.05 \\
\hline $\begin{array}{l}\text { Beneficiary settlements from the socio-economic and infrastructural } \\
\text { point of view and in terms of unemployment }\end{array}$ & 11.19 & 13.14 & 13.53 & 13.71 \\
\hline Non - beneficiary settlements & 3.15 & 3.41 & 4.20 & 4.74 \\
\hline Hungary & 3.98 & 4.35 & 5.12 & 5.62 \\
\hline
\end{tabular}

Source: National Employment Service, 2020. 
sitive protection measures were implemented in the hotspots of the epidemic (e.g. compulsory mask-wearing on public transport and in stores in Budapest). The restrictions started to be lifted gradually on $4^{\text {th }}$ May 2020, through the so-called sliding mode control displaying a marked territorial approach. Basically, it implied a relaxation of restrictions in less infected areas of the province, while in Budapest and Pest county, partial restrictions remained in force for two more weeks, and precautionary measures were strongly encouraged across the entire country.

Overall, the restrictive and mitigating measures designed to tackle the COVID-19 emergency had diverse territorial implications during the first wave of the pandemic in Hungary in the first half of 2020. In addition to granting settlements more room to manoeuvre in their containment efforts, the location of territorial focal points was also taken into account (in the capital city-countryside context), and the role of geographical isolation was emphasised in preventing group infections. If the relaxation of restrictions leads to a growing number of social interactions and, therefore, more confirmed cases, the government may return tighter restrictions nationally or regionally (e.g. in specific counties). This anticipates the cyclicality and spatially heterogeneous distribution (infected areas, focal points) of restrictions (exit ban, home karate, home school, etc.) in 2020. In the first phase of the struggle against the pandemic, Hungary managed to avoid mass infections and morbidity, but due to the permanent imminence of the pandemic threat, the state of epidemiological preparedness will remain in force over the second half of 2020.

In the spring of 2020, the Hungarian government introduced two rounds of measures to counter the effects of the economic crisis triggered by the pandemic. Anti-epidemic measures were based on a spatially blind approach and targeted various sectors or economic actors. At the first stage, the government announced a moratorium on loan payments from $18^{\text {th }}$ March 2020 extending to $31^{\text {st }}$ December 2020 and provided various benefits for struggling economic actors in different service sectors (e.g. passenger transport, tourism, hospitality or media services). In the most affected sectors, social security contributions were deferred for employers, while the rate of health care contributions was lowered. The most affected SMEs were exempt from the small business tax for 3 months.
On $6^{\text {th }}$ April 2020, additional economic measures were announced, financed by the newly created Economy Protection Fund. The focal points of these new measures are as follows:

- liquidity improvement (interest-subsidized and guaranteed credit facilities);

- job protection (short-time work program);

- job creation (wage subsidy and support for investments);

- support for priority sectors (tourism, agriculture, construction);

- and enhancing export competitiveness (support for investments).

The government also introduced measures to ensure that jobs are safeguarded such as wage subsidies paid to workers who were put on shortened work hours.

Since these are new measures, the only available information on their territorial aspects that we have covers a short-term period. According to government reports, the sectors of manufacturing, tourism and hospitality, trade, vehicle repair, transportation and warehousing were overrepresented among the wage support claimants. The majority of support applications were submitted by firms located in the capital city and Pest, Fejér, Györ-Moson-Sopron, Veszprém and Bács-Kiskun counties.

Regarding the rest of the measures, the lack of public information on the sectoral, territorial and size details of claimants poses an obstacle to their evaluation in terms of utility and selectivity. Basically, despite the wide range of sectors and economic actors affected by the two-phase implementation of the economy protection action plan, it represented the country as an integral unit and did not apply a territorially sensitive approach in the identification of individual actions and policy interventions.

The indirect territorial impacts of government interventions were enforced through decisions affecting local governments. On $6^{\text {th }}$ April 2020, a special decree was issued on the modification of the central budget related to the epidemiological state of emergency and the creation of three new funds - the Anti-Epidemic Fund, the Economy Protection Fund and the EU Pandemic Recovery Fund (Government Decree $92 / 2020$ ). Additionally, the government decided that these funds should be operated under the principle of burden sharing, entailing the withdrawal of $50 \%$ of support for parties, the introduction of a special tax in the banking sector, the 
re-allocation of various retail taxes and the imposition of severe cuts in local government funding.

The legislative measures placed local governments under the dual pressure stemming from their coordinating role in the organisation of local anti-epidemic efforts, and sharply declining revenues under the principle of burden-sharing (Kovács, 2020b):

- the tourist tax was suspended until the end of 2020, however, the decline in tourism would have implied substantial revenue losses for settlements in any case (Figure 6);

- $40 \%$ of the motor vehicle tax retained by local governments was channelled to the anti-epidemic fund (Figure 7);

- parking and public space use fees were temporarily waived;

- due to the economic downturn and reduced entrepreneurial solvency, a significant drop is anticipated in revenues from business taxes due in 2020 and realized by 2021 .

Revenue losses from measures to counter the negative effects of the pandemic may put local governments in a difficult situation, particularly in lagging areas with an unfavourable demographic structure (Warner, Aldag and Kim, 2020). This requires the government to elaborate new strategies and scenarios. Maher, Hoang and Hindery (2020) show that local authorities will first and foremost cut back on their discretionary spending, reschedule their maintenance and capital expenditures, reduce employee hours, and freeze their rental payments. On the contrary, they are less likely to implement tax and fee increases, layoffs, and suspend the provision of various services.

Local governments continue to play a key role in dealing with the effects of the pandemic: in the short run through containment efforts and provision of supply for those in need, and in the long run, through making decisions to counter the negative impacts (Baranyai, Barsi and Nárai, 2020).

Economic protection measures implemented under the epidemiological state of emergency in Hungary in the first half of 2020, while lacking an explicit territorial approach, point to the implicit presence of territorial perspectives in the fight against the epidemic. If the epidemic necessitates

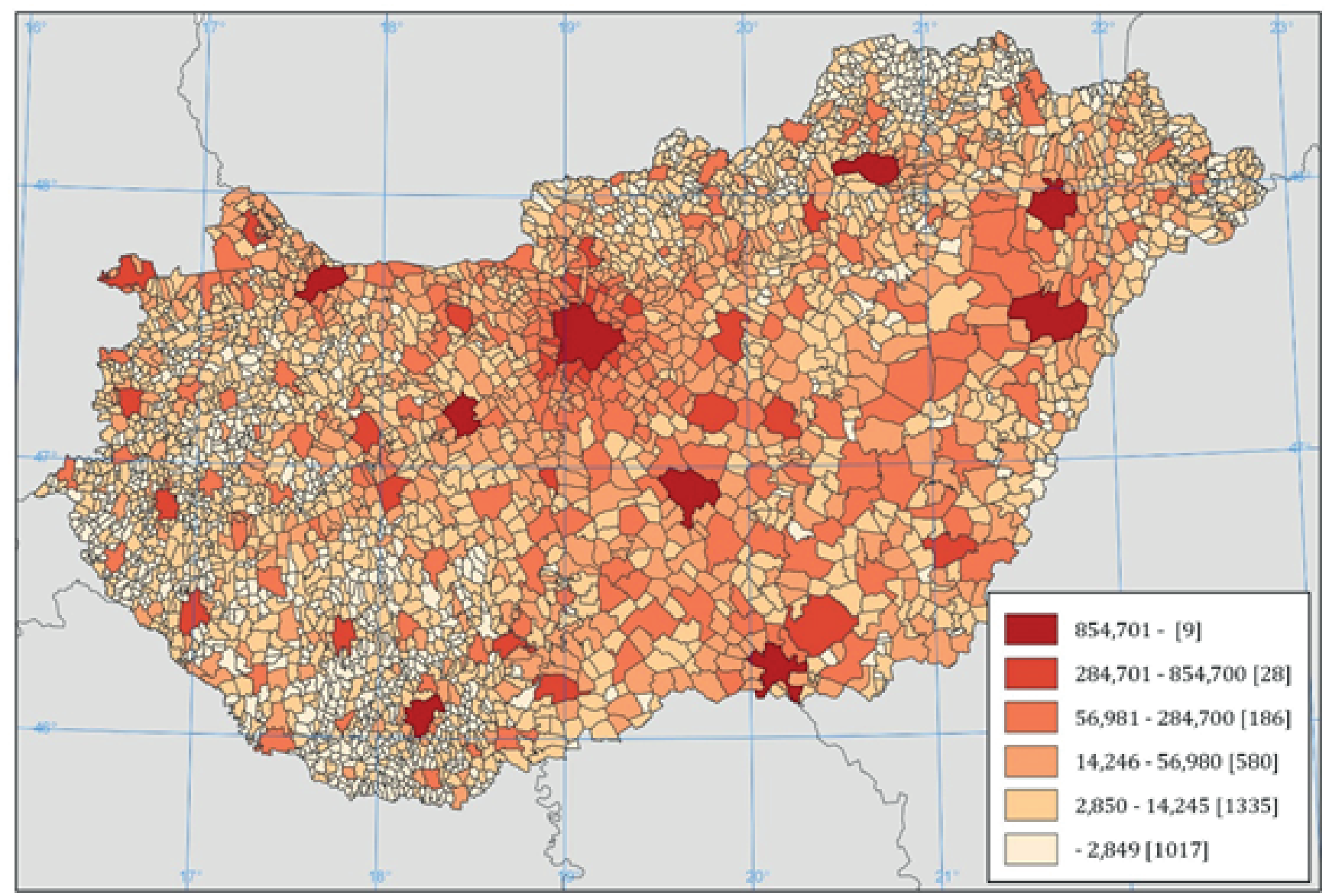

Figure 7. Volume of motor vehicle tax payments by settlements, 2017 (EUR) Source: Kovács, 2020b. p. 191 
further measures in the future, such measures can be conceived within institutional, local, or regional frameworks as well. For instance, out-of-classroom learning would not be imposed in every school, only in cases justified by epidemiological considerations.

Government measures are criticised for draining away a massive amount of financial resources from municipalities, while simultaneously transferring tasks and financing related to the prevention and containment of the epidemic (social services, preventive measures). In the meantime, municipalities were authorised to implement restrictive measures for a limited period (on weekends over a month). In the event of a new wave of the epidemic, this type of disinvestment will have to be more sensitive to spatial factors, to retain the resources in highly infected areas.

\section{Conclusion}

The global crisis caused by the COVID-19 pandemic has wide-ranging impacts across all economic sectors and social strata (Nicola et al., 2020), which will be felt in the upcoming years (Baldwin and Weder di Mauro, 2020). Not only must decision-makers take unprecedented steps to address the host of problems associated with the pandemic, but all of us have to change our behaviour in unexpected ways to prevent similar outbreaks in the future (UNDP, 2020).
Thus, the purpose of the paper is to provide a snapshot of Hungary recovering from the first wave of the pandemic, describing the government measures and their territorial implications. Overall, although the epicentre of the new coronavirus pandemic was the capital city and its surrounding area, its socio-economic impacts were felt across the entire country. While the government took into consideration the territorial aspects when devising measures for control and containment of the coronavirus pandemic in Hungary, they put considerably less emphasis on these aspects when dealing with the socio-economic consequences of the pandemic. Territorial monitoring and development of regionally differentiated policies are the main tasks in preparation for further waves of the pandemic. In addition, there is a need for more extensive economic protection measures to counter its adverse effects. If the crisis exacerbates territorial disparities, the government may have to devise measures to provide extra resources and support to lagging areas.

The most important principle of protection and prevention is the multi-national and multi-sectorial cooperation between all stakeholders, including governments, health professionals, media, non-governmental organizations, communities, and individuals and between the international agencies and national governments (Evans, 2020).

\section{References}

Baldwin, R., \& Weder di Mauro, B. (eds.) (2020): Mitigating the COVID Economic Crisis: Act Fast and Do Whatever It Takes. CEPR Press, London. $227 \mathrm{p}$.

Baranyai, N., Barsi, B., \& Nárai, M. (2020): Online communication of local governments during the COVID-19 pandemic in Hungary = Helyi önkormányzatok online kommunikációja a COVID-19 járvány idején Magyarországon. Space and Society = Tér és Társadalom, 34(3), 281-294. (In Hungarian)

Benedek, Zs., Balogh, P.G., Baráth, L., Fertő, I., Lajos, V., Orbán, É., Szabó, G.G., \& Nemes, G. (2020). What did the coronavirus add to farmers? = Mit hozott a gazdáknak a koronavírus? Retrieved from: https://www.portfolio.hu/krtk/20200611/mit-hozott-a-gazdaknak-a-koronavirus-436194 (In Hungarian)

Czech, K., Wielechowski, M., Kotyza, P., Benešová, I., \& Laputková, A. (2020): Shaking Stability: COVID-19 Impact on the Visegrad Group Countries' Financial Markets. Sustainability, 12, 6282. doi: $10.3390 /$ su12156282

COFIDIS (2020): The wallets of Hungarians do not plan ahead even during a crisis=Válságban sem tervez elöre a magyarok pénztárcája. Retrieved from: https://www.cofidis.hu/cofidis-hitel-monitor/valsagban-sem-tervez-elore-a-magyarok-penztarcaja.html (In Hungarian)

Evans, O. (2020): Socio-economic impacts of novel coronavirus: The policy solutions. BizEcons Quarterly, 7, 3-12. 
Farkas, J.Zs., \& Kovács, A. D. (2020): Environmental Context and Lessons from the COVID-19 Pandemic - Suggestions for a More Environmentally Conscious Society = A COVID-19 járvány környezeti összefüggései és tanulságai - felvetések egy környezettudatosabb társadalom érdekében. Quick analysis. CERS Institute for Regional Studies. http://www.docs.rkk.hu/rkkweb/FarkasJ-KovacsAD COVID-19 kornyezeti_osszefuggesek.pdf (In Hungarian)

Gombos, K., Herczeg, R., Erőss, B., Kovács, S. Zs., Uzzoli, A., Nagy, T., Kiss, Sz., Szakács, Zs., Imrei, M., Szentesi, A., Nagy, A., Fábián, A., Hegyi, P., \& Gyenesei, A. (2020): Translating Scientific Knowledge to Government Decision Makers Has Crucial Importance in the Management of the COVID-19 Pandemic. Population Health Management. doi: 10.1089/pop.2020.0159

Grünhut, Z., \& Bodor, Á. (2020): The culture of trust is on trial.Links among physical and mental health, social relations,subjective welfare and trust during pandemic = A fizikai (társadalmi) távolságtartástól a társadalmi szolidaritásig - A bizalom kultúrájának próbatételeA fizikai és lelki egészség, továbbá a társas kapcsolatok és a szubjektív anyagi helyzet összefüggései a bizalommal járványidöszakban. Space and Society = Tér és Társadalom, 34(3), 26-45. (In Hungarian)

Hajdú, Z., \& Rácz, Sz. (2020): Border policies in the European Union and Hungary in the initial period of the global COVID-19 crisis = Államhatár-politikák az Európai Unióban és Magyarországon a globális koronavírus-válság kezdeti időszakában. Space and Society = Tér és Társadalom, 34(2), 202-210. doi: 10.17649/TET.34.2.3260 (In Hungarian)

Hermann, Z. (2020): How many students do not reach online learning? = Hány diákhoz nem jut el az online távoktatás? Retrieved from: https://www.mtakti.hu/koronavirus/hany-diakhoz-nem-jut-elaz-online-tavoktatas/12769/ (Download: 23. April 2020.) (In Hungarian)

Jóna, L. (2020): Impact of the COVID-19 epidemic for the use and future of public spaces $=A$ COVID-19 járvány hatása a közösségi terek használatára és jövöjére. Space and Society = Tér és Társadalom, 34(3), 296-305. doi: 10.17649/TET.34.3.3289 (In Hungarian)

Kemenesi, G., Kornya, L., Tóth, G. E., Kurucz, K., Zeghbib, S., Somogyi, B. A., Zöldi, V., Urbán, P., Herczeg, R., \& Jakab, F. (2020): Nursing homes and the elderly regarding the COVID-19 pandemic: situation report from Hungary. GeroScience, 42, 1093-1099. doi: 10.1007/s11357-020-00195-Z

Kerényi, Á., \& Müller, J. (2019): Brave New Digital World? - Financial Technology and the Power of Information. Financial and Economic Review, 1, 5-32. doi: 10.33893/FER.18.1.532

Koós, B. (2020): Socio-spatial aspects of the Covid-19 pandemic in Hungary = A koronavírus-járvány társadalmi-területi aspektusai Magyarországon. Space and Society = Tér és Társadalom, 34(2), 156-177. doi: 10.17649/TET.34.2.3261 (In Hungarian)

Kovács, S. Zs., \& Uzzoli, A. (2020): Present and Future Health Risks and Their Regional Differences in Hungary Regarding COVID-19 Pandemic = A koronavírus-járvány jelenlegi és várható egészségkockázatainak területi különbségei Magyarországon. Space and Society = Tér és Társadalom, 34(2), 155-170. doi: 10.17649/TET.34.2.3265 (In Hungarian)

Kovács, S. Zs. (2020a): Limitations of putting of basic financial services on online space $=\mathrm{Az}$ alapvető pénzügyi szolgáltatások online térbe helyezésének korlátai. Space and Society = Tér és Társadalom, 34(2), 195-201. doi: 10.17649/TET.34.2.3264 (In Hungarian)

Kovács, S. Zs. (2020b): The possible future effects of widespread home office on the Hungarian internal migration patterns $=$ Revenue losses of local governments during pandemia $=$ Települési önkormányzatokat érintő bevételkiesések a járványhelyzetben. Space and Society = Tér és Társadalom, 34(2), 189-194. doi: 10.17649/TET.34.2.3263 (In Hungarian)

KPMG (2020): The COVID 19 pandemic could speed up digitalization of the Hungarian Banking Sector. Retrieved from: https://home.kpmg/hu/en/home/insights/2020/04/the-covid-19-pandemic-could-speed-up-digitalization-of-the-hungarian-banking-sector.html (Download: 23/07/2020)

KSH (2020a): The stagnant effect of the coronavirus epidemic on the economy broke the steady increase in retail sales in April $=A$ kiskereskedelmi forgalom többéves növekedését törte meg áprilisban a koronavírus okozta járvány gazdaságba begyürüzö hatása. Retrieved from: http://www.ksh.hu/docs/ hun/xftp/idoszaki/kiskereskedelmi-forgalom/index.html\#orszgosancskkentakiskereskedelmiforgalomjrsiszintenazonbanrnyaltabbakp (Download: 7/07/2020) (In Hungarian) 
KSH (2020b): The lack of foreign guests causes a significant loss of turnover and revenue. $=A$ külföldi vendégek elmaradása jelentös forgalom-és bevételkiesést okoz. Retrieved from: http://www. ksh.hu/docs/hun/xftp/idoszaki/kulf vendeg elmaradas/index.html\#akereskedelmiszllshelyekvendgeinekkzelfeleklfldi (Download: 7/07/2020) (In Hungarian)

KSH (2020c): Vacancies, Q1 of $2020=$ Üres álláshelyek, 2020. I. negyedév. Retrieved from: http://www.ksh.hu/docs/hun/xftp/idoszaki/ures-allashelyek/index.html (Download: 7/07/2020) (In Hungarian)

Lennert, J. (2020): A távmunka széleskörű elterjedésének lehetséges hatása a magyarországi vándormozgalomi mintázatokra. Space and Society = Tér és Társadalom, 34(2), 178-182. doi: $\underline{10.17649 /}$ TET.34.2.3269 (In Hungarian)

Maher, C. S., Hoang, T., \& Hindery, A. (2020): Fiscal Responses to COVID -19: Evidence from Local Governments and Nonprofits. Public Administration Review, 80(4), 644-650. doi: $10.1111 /$ puar. 13238

Nicola, M., Alsafi, Z., Sohrabi, C., Kerwan, A., Al-Jabir, A., Iosifidis, C., Agha, M., \& Aghaf, R. (2020): The socio-economic implications of the coronavirus pandemic (COVID-19): A review. International Journal of Surgery, 78, 185-193. doi: 10.1016/j.ijsu.2020.04.018

McKinsey and Company (2020): Consumer sentiment and behavior continue to reflect the uncertainty of the COVID-19 crisis. Retrieved from: https://www.mckinsey.com/business-functions/ marketing-and-sales/our-insights/a-global-view-of-how-consumer-behavior-is-changing-amidcovid-19\# (Download: 23. July 2020)

UNDP (2020): Putting the framework for socio-economic response to COVID-19 into action: Insights. UN, Geneva $17 \mathrm{p}$.

Uzzoli, A. (2020): Virus Geography 2.0 COVID-19: pandemic reloaded = Vírusföldrajz 2.0 COVID-19: világjárvány újratöltve! Földgömb, 2020/5-6. 38-49. (In Hungarian)

Varjú, V., Farkas, O., Farkas, J. Zs., \& Vér, Cs. (2020): Some environmental impact aspects of individual work-related car use change due to COVID-19 pandemic in Budapest = Az egyéni munkacélú személygépkocsi-közlekedés COVID-19 járvány következtében történő változásának némely környezeti aspektusa Budapesten. Space and Society = Tér és Társadalom, 34(2), 183-188. doi: 10.17649/TET.34.2.3266 (In Hungarian)

Warner, M. E., Aldag, A. M., \& Kim, Y. (2020). Pragmatic Municipalism: U.S. Local Government Responses to Fiscal Stress. Public Administration Review. doi: 10.1111/puar.13196

\section{Information about the authors}

Sándor Zsolt Kovács - MSc (Economics), junior research fellow, Institute for Regional Studies, Centre for Economic and Regional Studies (22. Papnövelde str., H-7621 Pécs, Hungary); e-mail: kovacs.sandor@krtk.mta.hu

Bálint Koós - PhD (Economics), research fellow, Institute for Regional Studies, Centre for Economic and Regional Studies (4. Tóth Kálmán str., H-1097 Budapest, Hungary); e-mail: koos.balint@ krtk.mta.hu

Annamária Uzzoli - PhD (Human Geography), senior research fellow, Institute for Regional Studies, Centre for Economic and Regional Studies (4. Tóth Kálmán str., H-1097 Budapest, Hungary); e-mail: uzzoli.annamaria@krtk.mta.hu

Balázs Páger - MSc (Economics), junior research fellow, Institute for Regional Studies, Centre for Economic and Regional Studies (22. Papnövelde str., H-7621 Pécs, Hungary); e-mail: pager.balazs@krtk.mta.hu

Ildikó Egyed - PhD (Economics), research fellow, Institute for Regional Studies, Centre for Economic and Regional Studies (22. Papnövelde str., H-7621 Pécs, Hungary); e-mail: egyed.ildiko@ krtk.mta.hu

ARTICLE INFO: received July 8, 2020; accepted August 30, 2020 


\section{Информация об авторах}

Ковач Шандор Жолт - магистр экономики, младший научный сотрудник, Институт региональных исследований, Центр экономических и региональных исследований (ул. Папновельде, 22, Н-7621 Печ, Венгрия); электронная почта: kovacs.sandor@krtk.mta.hu

Кош Балинт - PhD по экономике, научный сотрудник Института региональных исследований Центра экономических и региональных исследований (ул. Кальмана Тота, 4 , H-1097, Будапешт, Венгрия); электронная почта: koos.balint@krtk.mta.hu

Уццоли Аннамариа - $\mathrm{PhD}$ по географии, старший научный сотрудник Института региональных исследований, Центр экономических и региональных исследований (ул. Тот Кальмана, 4, Н-1097, Будапешт, Венгрия); электронная почта: Uzzoli.annamaria@krtk.mta.hu

Пагер Балаж - магистр экономики, младший научный сотрудник Института региональных исследований, Центр экономических и региональных исследований (ул. Папновельде, 22, Н-7621 Печ, Венгрия); электронная почта: pager.balazs@krtk.mta.hu

Едьед Ильдико - $\mathrm{PhD}$ по экономике, научный сотрудник Института региональных исследований Центра экономических и региональных исследований (ул. Папновельде, 22, H-7621 Печ, Венгрия); электронная почта: Individual.ildiko@krtk.mta.hu

ИНФОРМАЦИЯ О СТАТЬЕ: дата поступления 8 июля 2020 г.; дата принятия к печати 30 августа 2020 г. 